\title{
STn-KLH plus Detox Vaccine
}

National Cancer Institute

\section{Source}

National Cancer Institute. STn-KLH plus Detox Vaccine. NCI Thesaurus. Code C2501.

A vaccine comprised of a synthetic Sialyl-Tn antigen linked to the protein carrier, keyhole limpet hemocyanin $(\mathrm{KLH})$, administered with immunostimulant, Detox. Vaccination with ST n-KLH plus Detox may elicit an IgG-based anti-ST $n$ antibody response and ultimately a cytotoxic T-cell response against ST n-expressing cancer cells. 